\title{
Environmental impacts in Castro zone of the Paraná talc district, Brazil
}

\author{
ANTONIO CARLOS GONDIM; LUIZ EDUARDO MANTOVANI; HIDEO ARAKI
}

gondim@ufpr.br lem@ufpr.br haraki@geoc.ufpr.br

Federal University of Paraná - Brazil

(Received December 2002 Accepted December 2002)

\begin{abstract}

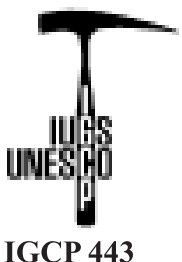

During the last two centuries, in Castro zone of the Paraná talc district in southern Brazil, native subtropical rain forest was exploited for wood and firewood use. During the last decade the exploitation process of the native forest has continued. In this paper it is presented a multi-temporal research about the impact of the native forest use. The chiefly aim is to discuss and illustrate the consequences of the use of forest and the absence of the reforest action in degraded areas in Castro zone of the Paraná talc district and the relation between the environmental impacts and the economic activities in the region.

The landscape impact of the mining activities is evident, although very limited in area if it is considered the territory in its totality. The main impact in the region is the deforestation. Through Landsat images it was possible to determine the changes that occurred in the land use in the region from 1990 to 2000. It is described the behavior of 4 classification entities: riparian forest, forest, cropland and bare soil. In these 10 years the main environmental impact is associated to forest reducing from $52 \%$ to $38 \%$ of the total area.

The deforestation was associated to wood industries in the past, nowadays it is linked to use of the soil to crop farms, firewood mainly to mining activities, especially lime-kiln and just few amount to dry talc ore product. In the last 3 years the firewood to dry talc was replaced by lumbermill dust that represents wastes in wood industries.
\end{abstract}

Key words: talc district, environmental impacts, multitemporal analysis.

\section{Introduction}

The Paraná talc district is situated in the First Plateau of the Paraná State, southern Brazil. It is in a subtropical climate, with rainfalls up to $1,400 \mathrm{~mm}$ p.y. and average temperature of approximately $16^{\circ} \mathrm{C}$.

This humid climate was very important to the development of a native forest with huge Araucaria angustifolia trees. In this region air, water and soil moisture are elevated all year long and this is a strong factor to the establishment and conservation of araucaria rain forest

Nevertheless, during the last two centuries native forest was exploited for wood and firewood use. High rainfall and relative low evapotranspiration produced high soil lixiviation and consequently natural acidity levels below $\mathrm{pH}$, with the presence of exchangeable aluminum and minor quantities of nutrients like potassium, calcium, magnesium and phosphate. These acid soils of the region restricted the agricultural activities to small subsistence crops and impoverished pasture for cattle, so only familiar dispersed farmers did live in this region.

The geology of the region of the Paraná talc district can be found in Souza (1990), Lima (1993), Reis Neto (1994), Ribas et al. (1999) and Gondim (2001). Figure 1 presents the geological map of the Castro zone of this district. Dolomite marbles host the talc deposits. There are morphologic controls represented by quartzites and dolerite dykes that protect the deposits against the erosion.

The metamorphic Itaiacoca Group is well marked by a succession of quartzites, metavolcanic rocks and dolomite marbles of different resistance to weathering and erosion. So, the relief takes its shape of a range of hills and low mountains oriented NE-SW; between them there are lowlands formed on dolomite marbles that exhibit carstic features and a thick soil mantle. The 


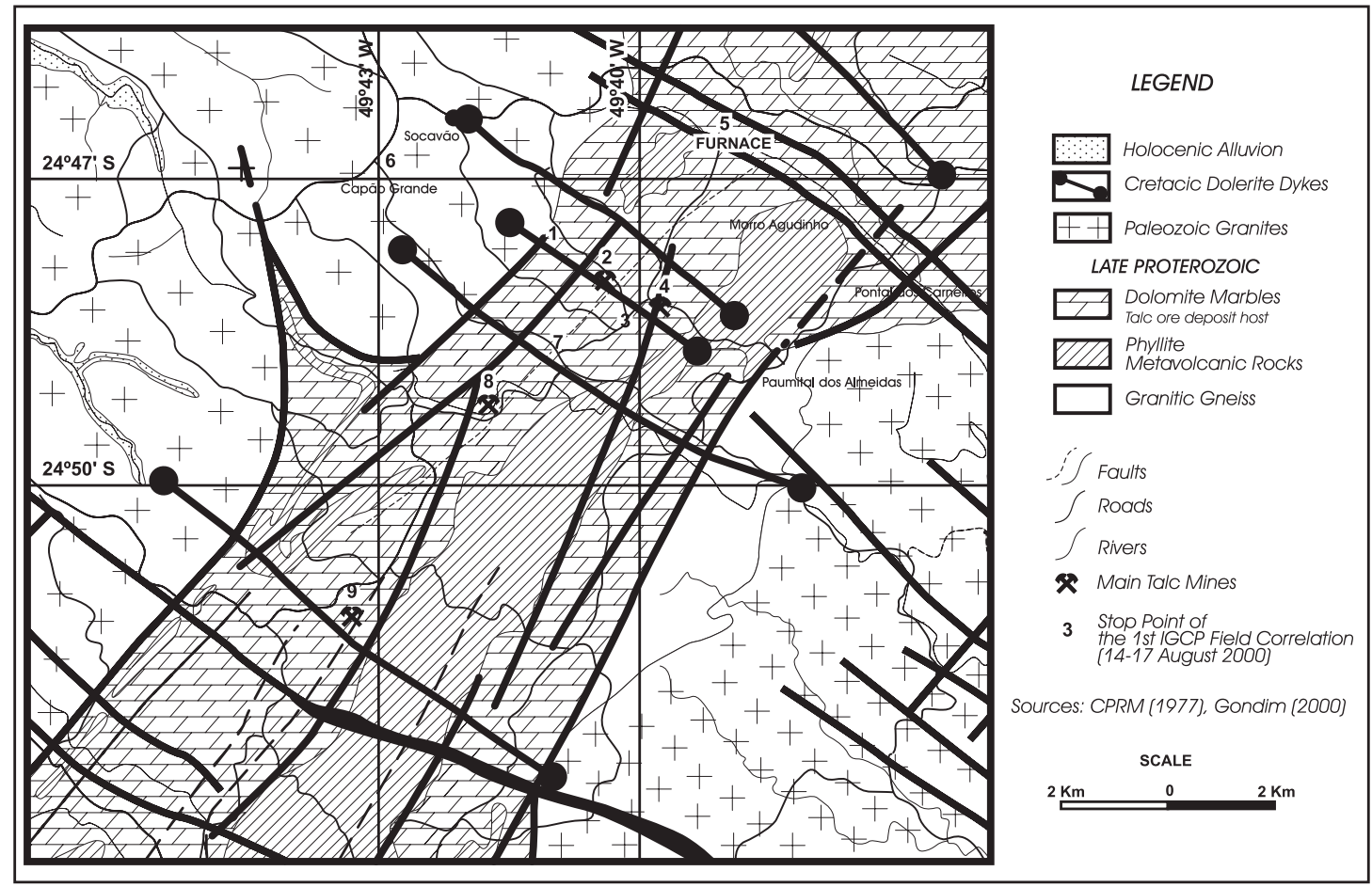

Fig. 1. Geological map of Castro zone of the Paraná talc district - Brazil.

resulting relief system may have approached the Appalachian landscape.

In the other hand several basal narrow but kilometric long cretaceous dolerites dikes cut the Proterozoic structures. When these dykes cut the dolomite marbles they create positive relief and negative one when they cut quartizites. An epigenetic drainage pattern was superimposed over the geological structures, so the main rivers cut the hard rocks forming gaps. This relief type makes the road communication difficult and was one of the reasons that the talc mines region remains isolated, with low demographic occupation and restrict economic activities. Besides talc and dolomite marble mining, there are ranches and few reforesting farms.

During the last decade the native forest exploitation process has continued. In this paper it is presented a multi-temporal research about the impact of the native forest use. The main aim is to discuss and illustrate the consequences of the indiscriminate use of forest and the absence of the reforesting action in degraded areas, in Castro zone of the Paraná talc district, and the relation among the environmental impacts and the economic activities in the region.

In this region, the strong environmental impact is related to the cut of native forest that presents several araucaria trees. The genus Araucaria had origin during the Jurassic and its fossils are found in several parts of the world (Salgado Laboriau, 1994). The rocky forests situated in Arizona, USA, and in Patagonia, Argentina, present Araucaria mirabilis material. Nowadays the Araucaria genus has 18 species, and its distribution is restricted to the template Australian region, New Zealand and the southern region of South America. In Brazil occurs Araucária angustifolia, the plentiful species in the forest of the Paraná talc district area.

The Araucaria is an important genus because, in general, in the forest it is associated with others species. According to Klein and Hatschbach (1962) several species occur associated to Araucaria as Ocotea porosa, Ocotea pretiosa, Sloanea lasiocoma, Minosa scabrella, Alchornea sp, Cedrella fissilis, Podocarpus lambertii, Guabirobeira Campomanesia xanthocarpa, Ilex paraguaiensis, Cryptocaria aschernoniana; Nectandra Megapotamica, Drimys brasiliensis, Chusquea sp, Merostachys sp, Solanum verbascifolium, Tillandsia sp, Rhipsalis pentaptera, Bignonia unguiscati, Sophronites grandiflora. Behling (1997) described the value of the ecosystem and the detail of the forest constitution in the Paraná State including the Castro area. 


\section{Environmental Impacts}

Talc and dolomite marble production, in the region of the Paraná talc district, represents a relatively new economic system and it carries several environmental impacts. One of them is the multiplicity of scarified mining terrains that sometimes are left after few years of exploitation. This fact is due the shallow mining in the area. The miners avoid penetrating deeper because the piezometric level can be hard to control, especially on carstic relief.
The landscape impact of the mining activities is evident, although very limited in area if it is considered the territory in its totality.

Indeed other impacts less visible cause bigger environmental damage than the open pit. In the Paraná talc district the ore needs to dry before being transported by trucks to beneficiating plants. This process is made in industrial furnaces warmed by firewood obtained in the local forest causing environmental impact. Nevertheless, this impact is smaller than others activities as tillage, industrial wood and the firewood used to

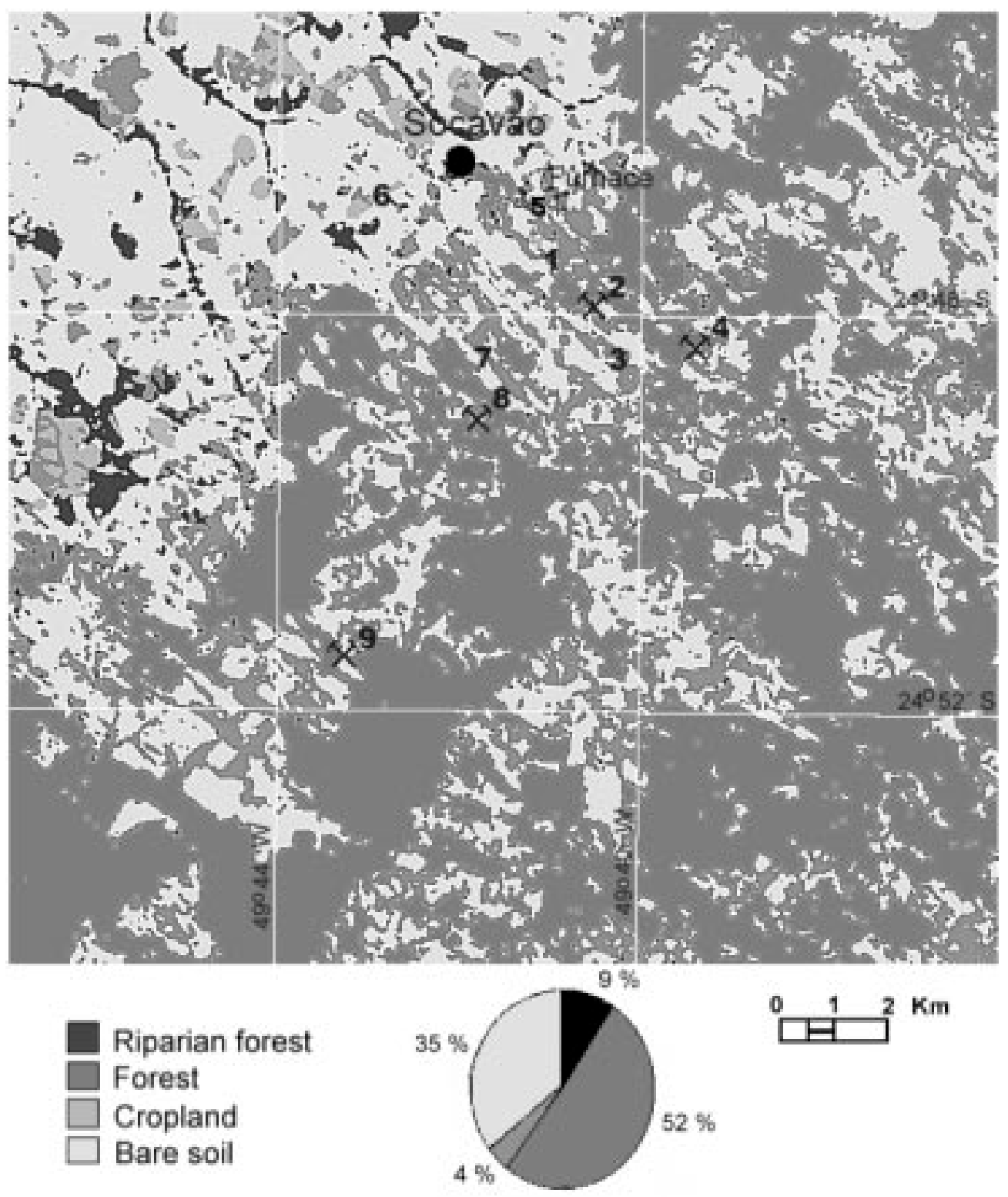

Fig. 2. Image LANDSAT with supervised classification of land cover in 1990 - Castro zone of the Paraná talc district - Brazil. 
dolomite marble beneficiating, as discussed in the following.

In Figures 2 and 3 it is possible to compare the change in area of the vegetation cover in Castro zone of the Paraná talc district, between 1990 and 2000.

The Figure 2 exhibits a supervised classification of the image of LANDSAT-5, TM sensor, obtained in 1990 July, during the winter in the region. The Figure 3 exhibits the supervised classification of the image of
LANDSAT-7, TM sensor, obtained in 2000 September, during the spring in the region. The bands 3,4 and 5 were used, being respectively visible, near infrared and medium infrared. So the band number 3 and 4 were employed to detect the presence of vegetation cover. The band number 5 enhances the representation in the image of bare soil and also enhances the contrast among vegetation cover, forest, cropland and pasture. The use of these three bands is recommended to identify the

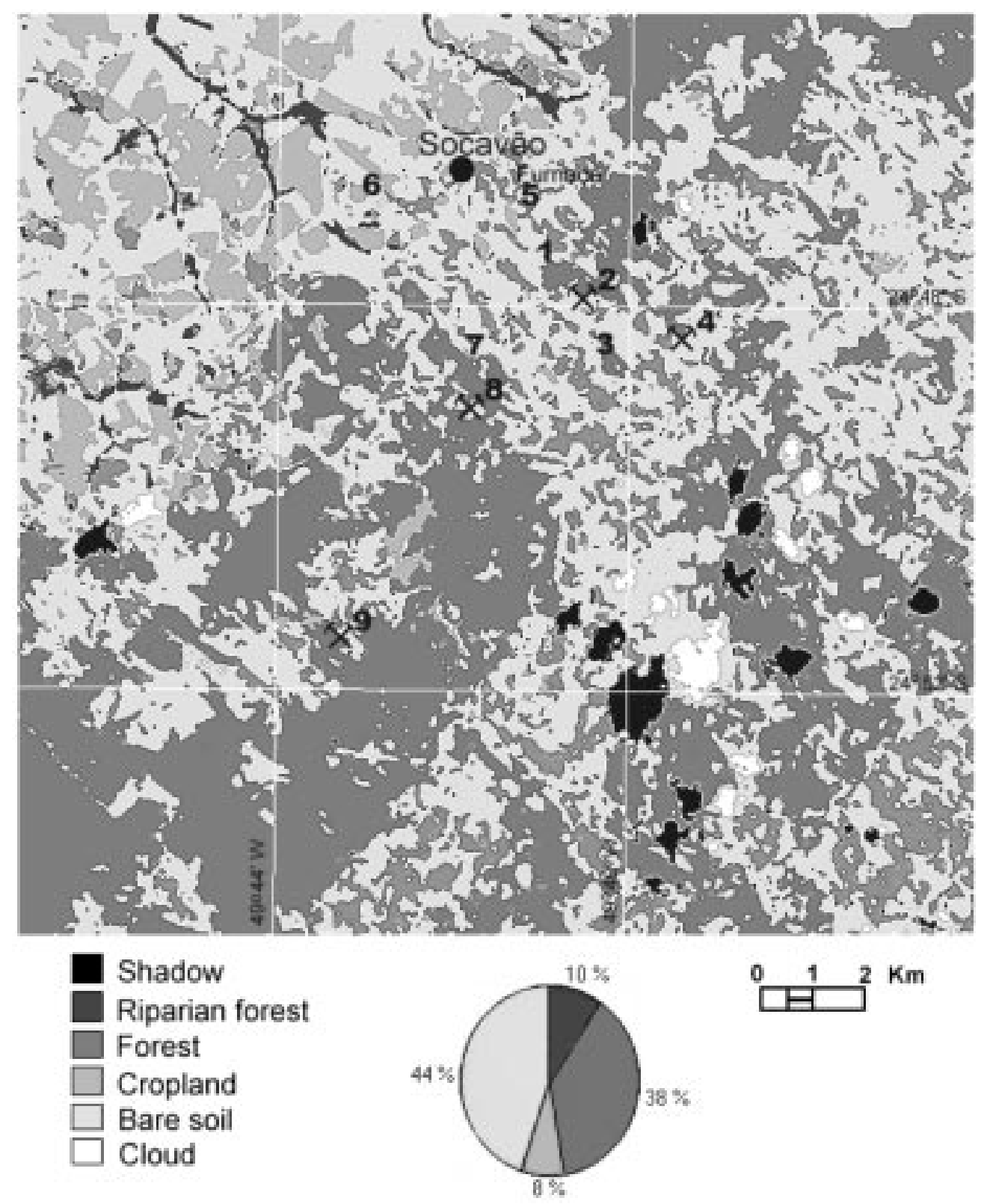

Fig. 3. Image LANDSAT with supervised classification of land cover in 2000 - Castro zone of the Paraná talc district - Brazil. 
differences among the several types of land use. In the Castro region there is no important change from winter to spring seasons in the forest reflectance, and then it is possible to compare the images obtained in these different seasons.

In the classification of the images 4 classes of land cover were determined: riparian forest, forest, cropland and bare soil. In the image of the year 2000 it is possible to observe the presence of clouds and its respective shadows affecting only $3.4 \%$ of the total area, but in the calculus of the percents of each class they were distributed $50 \%$ for each class where they occurred, in forest and bare soil.

When the analysis and comparison of the LANDSAT images obtained in 1990 and 2000 is made, in terms of the intensity of deforestation, it is possible to verify that the process was very hard. Despite all laws and rules that exist nowadays in Brazil to control and limit clear-cut, especially in the southern and southeastern Brazilian States, the rate of deforestation of $27 \%$ in 10 years is a menace to the remains of subtropical araucaria rain forest. The 1990 image shows an even pattern of forest and small areas of bare soils between them. Only over the oxisols on the gently hilly terrain over the Cunhaporanga batholitic granite, situated in northwestern area (see Figure 1), the land use showed large areas of pasture and agriculture (Figure 2). Ten years after the situation was radically changed. The fragmentation of forest areas spread over the entire southeastern zone. Only over rock shallow entisols and high interchangeable aluminum content impoverished soils the deforestation was less intensive. These soils are well linked with the phyllites of the Itaiacoca Group and are also oriented NE-SW like the forest coverage in the talc mines region.
The image classification in the Paraná talc district shows important changes in land use between 1990 and 2000. In these 10 years the forest reduced its area from $52 \%$ to $38 \%$ of the total area, while the riparian forest much more protected by environmental agencies remains almost the same (4\% and 5\% respectively). Cropland has, in 2000, twice the area than it had ten years before, changing from $4 \%$ to $8 \%$ of the total area. By the way, bare soils were increased from $35 \%$ to $44 \%$ (see Figures 2 and 3).

The general landscape analysis reveals that the direct impacts of talc mining are relatively small and only circumscriptive to the open pits, but when it is considered the whole aspects it is possible to link one part of the wood cutting to the activity of drying the talc ore. Nevertheless, in this region the deforestation was associated in the past with the wood industries. Nowadays, it is chiefly linked to the agricultural expansion beyond the dolomite marble mining to liming and lime-kiln. The agriculture demands more space which was previously occupied by the forest, and the manufacturing processes of liming and lime-kiln demands more firewood than talc beneficiation.

Moreover, the firewood consumption, for drying talc ore, was intensive only until 3 years ago, when the substitution of this product for lumber-mill dust started. Lumber-mill dust represents waste in wood industries of the region.

Finally the burning process which represents a powerful factor in deforestation of Amazon region, it is not often practice in Castro zone of the Paraná talc district in southern Brazil.

\section{References}

Behling, H. Late Quaternary vegetation, climate and fire history of the Araucaria forest and campos region from Serra Campos Gerais, Paraná State (South Brazil). Review of Paleobotany and Palynolgy, 97, 1997, p. 109-121.

CPRM 1977 Projeto leste do Paraná. Mapa geológico 1:100 000 Folha Piraí do Sul. CPRM, Convênio DNPM - BADEP UFPR, Relatório Final.

Gondim, A. C. 2000 First Field Correlation - Talc deposits of the Paraná State - Brazil. IGCP/IUGS/UNESCO 443, Curitiba $14 \mathrm{p}$.
Gondim, A. C. (2001) Exploration of talc deposits in Paraná State, Brazil. Mineralia Slovaca, 33 (6): 575-578.

Klein, B. M. \& Hatschbach, G. Fitofisionomia e notas sobre a vegetação para acompanhar a planta fitogeográfica do município de Curitiba e arredores (Paraná). Boletim da Universidade do Paraná. Curitiba: UFPR. n. 4. 1962.

Lima, R. E. de 1993 Evolução geológica e controles dos depósitos de talco da região Itaiacoca-Abapã/PR. Inst. De Geociências, UNB, Brasília, Dissertação de Mestrado, 139 p. 
GONDIM, A. C. et al. Environmental impacts in Castro zone of the Paraná talc district, Brazil

Reis Neto, J. M. 1994 Faixa Itaiacoca: registro de uma colisão entre dois blocos continentais no Neoproterozóico. Inst. de Geociências - USP, São Paulo, Tese de doutorado, 253 p.

Salgado Laboriau, M.L. História Ecológica da Terra. São Paulo: Edgard Blucher, 1994.
Souza, A. P. 1990 Mapa geológico na escala 1: 50000 e esboço da evolução tectônoca e sedimentar do Grupo Itaiacoca, nas folhas Barra do Chapéu e Ouro Verde - SP/PR. Inst. De Geociências - USP, São Paulo. Dissertação de mestrado, 200 p. 